\title{
Failure to Confirm the Presence of a Retrovirus in Cultured Lymphocytes from Patients with Kawasaki Syndrome
}

\author{
ANNE ROWLEY, BLESILA CASTRO, JAY LEVY, JOHN SULLIVAN, RICHARD KOUP, \\ RAOUL FRESCO, AND STANFORD SHULMAN \\ Children's Memorial Hospital and Northwestern University Medical School, Chicago, Illinois 60614 [A.R., S.S.]; \\ University of California, San Francisco. California 94143 [B.C., J.L.]; University of Massachusetts, \\ Worcester, Massachusetts 01605 [J.S., R.K.]; and Loyola University Medical School, \\ Maywood, Illinois 60153 [R.F.]
}

\begin{abstract}
We and others previously reported DNA polymerase activity in culture supernatants of peripheral blood mononuclear cells from patients with acute Kawasaki syndrome (KS). In the present study, we further characterized the previously detected polymerase activity and attempted to confirm its presence in cultured peripheral blood mononuclear cells from additional patients with $\mathrm{KS}$. Characterization experiments indicated that the polymerase activity was typical of a DNA-dependent DNA polymerase rather than viral reverse transcriptase. Peripheral blood mononuclear cell cultures from 17 additional KS patients were negative for reverse transcriptase activity in three laboratories. Our findings do not provide support for a retroviral etiology of KS. Further studies should continue to focus on infectious agents in efforts to elucidate the etiology of KS. (Pediatr Res 29: 417-419, 1991)
\end{abstract}

Abbreviations

KS, Kawasaki syndrome

PBMC, peripheral blood mononuclear cell

AMV, avian myeloblastosis virus

PHA, phytohemagglutinin

poly(rA) oligo(dT), template-primer

poly(dA) oligo(dT), template-primer

poly $(\mathbf{r C})$ oligo $(\mathrm{dG})$, template-primer

KS is an acute febrile illness of childhood of unknown etiology, characterized by rash, conjunctival injection, red lips, swollen, erythematous hands and feet, and cervical adenitis. Twenty \% of untreated patients develop coronary artery aneurysms (1). In September 1986, we reported preliminary evidence of DNA polymerase activity in culture supernatants of PBMC obtained from eight of 18 patients with acute $\mathrm{KS}$, and suggested the possibility that a retrovirus might be related etiologically to the illness (2). Burns et al. (3) reported similar findings in cultured PBMC from five of 14 patients with $\mathrm{KS}$, demonstrated maximal polymerase activity at a buoyant density of $1.18-1.22 \mathrm{~g} / \mathrm{mL}$ of sucrose, and reported the presence of viral-like intracellular particles in rare PBMC by electron microscopy.

Melish et al. (4) recently reported results on studies of PBMC

Received May 25, 1990; accepted January 4, 1991.

Correspondence and reprint requests: Anne H. Rowley, M.D., Division of Infectious Diseases, The Children's Memorial Hospital, 2300 Children's Plaza, Box 20, Chicago, IL 60614.

Supported in part by the Kawasaki Disease Research Fund of the Children's Memorial Hospital cultures from 36 patients with KS. Low-level DNA-dependent DNA polymerase activity was detected in some patients with acute KS, but RNA-dependent DNA polymerase activity characteristic of retroviruses was not observed. It was concluded that the polymerase activity detected was of cellular origin and that there was no evidence to support a retroviral etiology for KS. Several groups in Japan also performed cultures of PBMC from patients with $\mathrm{KS}$, concluding that reverse transcriptase activity could not be detected (5-9). More recently, Burns et al. (10) reported observations of the template-primer specificity of pooled supernatants demonstrating polymerase activity in their laboratory and again suggested that an RNA-directed DNA polymerase consistent with reverse transcriptase is present in cultured PBMC from patients with $\mathrm{KS}$.

We report here the results of further studies to characterize our previously detected polymerase activity (2) and of attempts to confirm its presence in cultured PBMC from additional patients with $\mathrm{KS}$.

\section{MATERIALS AND METHODS}

Characterization of polymerase activity in stored samples. Polymerase assays were performed as previously described (2) on stored $\left(-70^{\circ} \mathrm{C}\right)$ culture supernatants that previously showed polymerase activity. The only modification was that in these studies culture supernatants were filtered $(0.45 \mu \mathrm{m})$ rather than slowspun before the ultracentrifugation step in the polymerase assay. Poly(rA) oligo(dT) and poly(rC) oligo(dG) or poly(dA) oligo(dT) (Sigma Chemical Co., St. Louis, MO) were used as template primers in separate assays on aliquots of the same samples. ${ }^{3} \mathrm{H}-$ thymidine triphosphate $(77.9 \mathrm{Ci} / \mathrm{mmol}$ ) (New England Nuclear, Boston, MA) was used in assays with poly(rA) oligo(dT) and poly(dA) oligo(dT), and ${ }^{3} \mathrm{H}$-guanosine triphosphate (New England Nuclear) $(12.1 \mathrm{Ci} / \mathrm{mmol})$ was used in assays with poly $(\mathrm{rC})$ oligo(dG). Dideoxythymidine (graciously provided by Dr. Hiroaki Mitsuya of the National Cancer Institute, Bethesda, MD) was added to the standard polymerase assay [utilizing poly(rA) oligo(dT) as template primer] at concentrations of 0.1 or $1 \mathrm{mM}$. In addition, three cell-free supernatants $(1 \mathrm{~mL}$ each $)$ that demonstrated initial polymerase activity were cultured with fresh MOLT-3 and MOLT-4 cells as previously described (2), and polymerase assays were performed on culture supernatants at weekly or twice-weekly intervals. For all characterization experiments, AMV reverse transcriptase (Boehringer Mannheim, Indianapolis, IN) was used as a control. Because of limited volumes of stored culture supernatants, not all methods could be performed on each supernatant. Rather, separate supernatants were used for selected tests. Transmission electron microscopy was performed on cells withdrawn from cultures with polymerase- 
positive supernatants at the time the positive result was obtained, usually at 2-3 wk after initiation of the culture.

Attempts to confirm presence of polymerase activity in additional KS patient PBMC. PBMC cultures from $17 \mathrm{KS}$ patients were performed on duplicate specimens in two laboratories: 1) Children's Memorial Hospital and 2) the University of California at San Francisco or the University of Massachusetts. Three to 6 $\mathrm{mL}$ of heparinized blood was shipped overnight at room temperature to the University of California (11 patients) or the University of Massachusetts (six patients), and cultures were established the following day. All patients fulfilled classic diagnostic criteria for $\mathrm{KS}$, and blood was obtained on $\mathrm{d} 4-8$ after the onset of illness. Cell cultures and polymerase assays were performed in the Children's Memorial Hospital laboratory as previously described (2). In addition, co-cultures of patient buffy coat cells with human T-lymphoblastoid cell lines and co-cultures of patient PBMC with human umbilical vein endothelial cells isolated by an adaptation of the method of Gimbrone (11) were established and twice weekly polymerase assays performed on culture supernates. In this laboratory, negative controls included reaction mix without sample, which yielded a polymerase activity of $0-5000 \mathrm{cpm} / \mathrm{mL}$, and co-cultivation supernatants of control PBMC with lymphoblastoid cell lines, which yielded a polymerase activity $<10000 \mathrm{cpm} / \mathrm{mL}$. A positive control consisting of a dilution of AMV reverse transcriptase enzyme that consistently yielded polymerase activity of $20000 \mathrm{cpm} / \mathrm{mL}$ was included in each run. A value of $>15000 \mathrm{cpm} / \mathrm{mL}$ was considered positive. Methods used at the University of Massachusetts laboratory have been described in detail elsewhere (12). In addition, in the University of Massachusetts laboratory, four KS patient PBMC were cultured with the human T-cell line CEM A3.01 (kindly provided by Thomas Folks, Centers for Disease Control, Atlanta, GA), and three patient PBMC were cultured with U937, a monocyte/macrophage cell line, as previously described (13). In this laboratory, a negative control consisting of phytohemagglutinin stimulated uninfected PBMCs yielding polymerase activity of $<1000 \mathrm{cpm} / \mathrm{mL}$ is employed, and $>10000 \mathrm{cpm} / \mathrm{mL}$ is considered positive. At the University of California at San Francisco laboratory, PBMC from KS patients were cultured by three methods. Method A consisted of PBMC culture with the addition of PHA at $3 \mu \mathrm{g} / \mathrm{mL}$ on d 0 . Method B involved co-culture of KS patient PBMC with normal PBMC that had been stimulated with PHA for $3 \mathrm{~d}$. Method $\mathrm{C}$ involved culture of adherent cells (monocytes) from the KS patient, with the addition of normal PHA-stimulated PBMC on $\mathrm{d} 7$. Cultures and polymerase assays otherwise were performed as previously described (14). Cultures from seven patients were assayed for polymerase activity in the presence of magnesium and those from four patients were assayed in the presence of magnesium and manganese. In this laboratory, negative controls for magnesium yield polymerase activity of $0-5000 \mathrm{cpm} / \mathrm{mL}$, and $>10000 \mathrm{cpm} / \mathrm{mL}$ is considered positive. Negative controls for manganese yield polymerase activity of approximately $9500 \mathrm{cpm} / \mathrm{mL}$, and human T lymphotropic virus-1-positive control yields counts of approximately $500000 \mathrm{cpm} / \mathrm{mL}$.

\section{RESULTS}

Characterization of polymerase activity in stored supernatants. Ten stored positive supernatants were subjected to the characterization experiments. Because of small sample volumes, all tests could not be performed on each sample. Rather, each supernatant was allocated to a separate characterization experiment. Frozen supernatants yielded equivalent polymerase activity compared with fresh supernatants within $3000 \mathrm{cpm} / \mathrm{mL}$.

Polymerase activity could not be successfully passed from frozen polymerase-positive supernatant samples from three patients to fresh MOLT-3 or MOLT-4 cells. Template-primer specificity studies yielded equivalent activity with poly(rA) oligo(dT) and with poly(dA) oligo(dT) for two pooled positive supernatants and no detectable activity with poly $(\mathrm{rC})$ oligo(dG) for two other pooled positive supernatants. There was no significant inhibition of enzyme activity by dideoxythymidine at 0.1 or $1 \mu \mathrm{M}$ on any of the three additional positive supernatants tested, but AMV reverse transcriptase activity was completely inhibited at both concentrations (Table 1). Electron microscopic studies on frozen stored cells from 15 PBMC cultures from 11 patients that demonstrated polymerase activity did not reveal any viral particles in or near cells.

Polymerase activity in PBMC from Kawasaki patients. No polymerase activity was detected in 17 duplicate sets of cultures of PBMC from 17 acute KS patients performed in two laboratories. The PBMC from six patients with acute $\mathrm{KS}$ evaluated at Children's Memorial Hospital had polymerase assays demonstrating $<10000 \mathrm{cpm} / \mathrm{mL}$, and PBMC cultures from the same six patients at the University of Massachusetts were all $<1000$ $\mathrm{cpm} / \mathrm{mL}$. The PBMC from 11 additional patients studied at Children's Memorial again demonstrated $<10000 \mathrm{cpm} / \mathrm{mL}$ on polymerase assay, and PBMC cultures from the same 11 patients at the University of California at San Francisco were all $<5000$ $\mathrm{cpm} / \mathrm{mL}$ by all the procedures employed using magnesium as the divalent cation and $<15000 \mathrm{cpm} / \mathrm{mL}$ using manganese as the divalent cation. Buffy coat cultures from three patients and endothelial cell co-cultures from two KS patients also did not yield polymerase activity above $10000 \mathrm{cpm} / \mathrm{mL}$. The results of these culture attempts are depicted in Table 2.

\section{DISCUSSION}

Clinical and epidemiologic features of KS are consistent with a probable infectious etiology for the illness (15). The striking immunoregulatory abnormalities present in the acute stage of KS (16) suggest that a lymphotropic agent may be involved. For these reasons, we tested the hypothesis that a retrovirus is etiologically related to the illness. Although our initial data were supportive of this possibility, subsequent investigations, as reported here, were not. Our findings are therefore in agreement with those of several other groups of investigators (4-9) who have failed to confirm an association between retroviruses and

Table 1. Characterization of 10 stored supernatants*

\begin{tabular}{|c|c|c|}
\hline Sample no. & Experiment & Polymerase activity result \\
\hline 1 & $\begin{array}{l}\text { Passage to fresh MOLT-3 } \\
\text { or MOLT- } 4 \text { cells }\end{array}$ & $\begin{array}{l}\text { No activity }>10000 \mathrm{cpm} / \mathrm{mL} \\
\text { detected in new cultures }\end{array}$ \\
\hline 2 & $\begin{array}{l}\text { Passage to fresh MOLT-3 } \\
\text { or MOLT- } 4 \text { cells }\end{array}$ & $\begin{array}{l}\text { No activity }>10000 \mathrm{cpm} / \mathrm{mL} \\
\text { detected in new cultures }\end{array}$ \\
\hline 3 & $\begin{array}{l}\text { Passage to fresh MOLT- } 3 \\
\text { or MOLT- } 4 \text { cells }\end{array}$ & $\begin{array}{l}\text { No activity }>10000 \mathrm{cpm} / \mathrm{mL} \\
\text { detected in new cultures }\end{array}$ \\
\hline \multirow[t]{2}{*}{$\begin{array}{l}4 \\
5\end{array}$ (pooled) } & $\begin{array}{l}\text { A) Poly rA oligo dT } \\
\text { B) Poly dA oligo dT }\end{array}$ & Sample: $\begin{aligned} A & =20100 \mathrm{cpm} \\
B & =20600 \mathrm{cpm}\end{aligned}$ \\
\hline & & $\begin{array}{l}\text { AMV RT control: } \\
\qquad \begin{array}{l}\mathrm{A}=1300000 \mathrm{cpm} \\
\mathrm{B}=10400 \mathrm{cpm}\end{array}\end{array}$ \\
\hline \multirow[t]{2}{*}{${ }_{7}^{6}$ (pooled) } & $\begin{array}{l}\text { A) Poly rA oligo dT } \\
\text { B) Poly rC oligo dG }\end{array}$ & Sample: $\begin{aligned} A & =0.74 \mathrm{pmol} \\
B & =0.08 \mathrm{pmol}\end{aligned}$ \\
\hline & & $\begin{array}{l}\text { AMV RT control: } \\
\qquad \begin{aligned} \mathrm{A} & =2 \mathrm{pmol} \\
\mathrm{B} & =11.2 \mathrm{pmol}\end{aligned}\end{array}$ \\
\hline \multirow[t]{2}{*}{${ }_{9}^{8}$ (pooled) } & $\begin{array}{l}\text { Addition of ddT } \\
\text { A) Without ddT }\end{array}$ & Sample: $\begin{aligned} A & =20400 \mathrm{cpm} \\
B & =12500 \mathrm{cpm}\end{aligned}$ \\
\hline & B) With ddT & $\begin{array}{l}\text { AMV RT control: } \\
\qquad \begin{aligned} \mathrm{A}=38500 \mathrm{cpm} \\
\mathrm{B}=1000 \mathrm{cpm}\end{aligned}\end{array}$ \\
\hline \multirow[t]{2}{*}{10} & $\begin{array}{l}\text { Addition of ddT } \\
\text { A) Without ddT }\end{array}$ & Sample: $\begin{aligned} A & =22000 \mathrm{cpm} \\
B & =17600 \mathrm{cpm}\end{aligned}$ \\
\hline & B) With ddT & $\begin{array}{l}\text { AMV RT control: } \\
\qquad \begin{aligned} \mathrm{A}=29600 \mathrm{cpm} \\
\mathrm{B}=2800 \mathrm{cpm}\end{aligned}\end{array}$ \\
\hline
\end{tabular}

* AMV RT, AMV reverse transcriptase; ddT, dideoxythymidine. 
Table 2. PBMC culture results in 17 patients with Kawasaki syndrome

\begin{tabular}{ccc}
\hline Patient no. & Culture method* & $\begin{array}{c}\text { Reverse } \\
\text { transcriptase activity } \ddagger\end{array}$ \\
\hline 1 & A, B, D & - \\
2 & A, B, D & - \\
$3-9$ & B, D $~$ & - \\
10 & B, C, D, H & - \\
11 & B, C, D, H & - \\
$12-14$ & B, E, F & - \\
15 & B, E, H & - \\
$16-17$ & B, G & -
\end{tabular}

* A, PHA: treatment for $3 \mathrm{~d}$; B, co-culture of patient PBMC with normal PBMC; $C$, patient macrophages cultured and normal PBMC added on $d 7 ; \mathrm{D}$, patient PBMC co-cultured with MOLT-3; E, patient PBMC co-cultured with CEM A3.01; F, patient PBMC co-cultured with U937; G, patient PBMC co-cultured with endothelial cells; and $\mathrm{H}$, culture of patient buffy coat cells, not subjected to Ficoll-Hypaque separation.

$\dagger$ Patients 5-17 with $\mathrm{Mg}^{++}$; patients $1-4$ with $\mathrm{Mg}^{++}$and $\mathrm{Mn}^{++}$.

$\ddagger$ See text.

KS. In this regard, recent studies by Burns et al. (17) using in vitro amplification of $\mathrm{KS}$ patient $\mathrm{PBMC}$ by the polymerase chain reaction with oligonucleotide primers derived from highly conserved retroviral sequences (18) detected only endogenous human retroviral sequences, without evidence of any retroviral sequences not present in control PBMC.

Studies of frozen co-culture supernatants that had previously been demonstrated to have polymerase activity (2) revealed equivalent results with poly(rA) oligo(dT), which can be used by both RNA- and DNA-directed enzymes, and with poly(dA) oligo(dT), which is used only by DNA-directed enzymes. The polymerase assay using poly $(\mathrm{rC})$ oligo(dG) as template, which is specific for RNA-directed enzymes such as reverse transcriptase, was negative. Moreover, attempts to pass the observed polymerase activity to fresh cells were not successful. In addition, polymerase activity was not inhibited by dideoxythymidine, an inhibitor of reverse transcriptase but not of DNA polymerase- $\alpha$ of host cell origin. Finally, all electron microscopic studies of PBMC from KS patients were negative. Therefore, the polymerase activity detected initially in the supernatants of cultured PBMC from KS patients appears to be primarily or exclusively DNA-directed.

In addition, in the present studies we were unable to confirm any polymerase activity in supernatants from PBMC cultures from 17 other KS patients. The absence of any polymerase activity in cultures from these recent patients with $\mathrm{KS}$ may reflect the greater attention given to minimizing possible cellular contamination (e.g. filtering supernatants and subtracting a poly(dA) oligo(dT) control from polymerase assay results).

Although Burns et al. (10) have suggested that polymerase activity is more likely to be detected from PBMC cultures obtained from KS patients during early convalescence, at least six samples obtained from KS patients at 4-6 wk after the onset of illness have been negative for polymerase activity in our laboratory.

Our findings do not provide support for a retroviral etiology of KS. We believe, however, that future etiologic studies should continue to focus on infectious causes, in keeping with the epidemiologic and clinical features of the illness. Emphasis should be given to agents that might cause the unusual lymphocyte abnormalities observed in patients with $\mathrm{KS}$.

\section{REFERENCES}

1. Rowley AH, Gonzalez-Crussi F, Shulman ST 1988 Kawasaki syndrome. Rev Infect Dis 10:1-15

2. Shulman ST, Rowley AH 1986 Does Kawasaki disease have a retroviral etiology? Lancet 2:545-546

3. Burns JC, Geha RS, Schneeberger EE. Newburger JW, Rosen FS, Glezen LS, Huang AS, Natale J, Leung DYM 1986 Polymerase activity in lymphocyte culture supernatants from patients with Kawasaki disease. Nature 323:814816

4. Melish ME, Marchette NJ, Kaplan JC, Kihara S, Chind D, Ho DD 1989 Absence of significant RNA-dependent DNA polymerase activity in lymphocytes from patients with Kawasaki syndrome. Nature 337:288-290

5. Okamoto T, Kuwabara H, Shimotohno K, Sugimura T, Yanase Y, Kawasaki T 1988 Lack of evidence of retroviral involvement in Kawasaki disease. [letter] Pediatrics 81:599

6. Abe J, Hirama M, Yoshida T, Nakayama M, Kohsaka T, Kobayashi N 1988 Does reverse transcriptase really exist in culture supernatants of lymphocytes from Kawasaki disease patients? Proceedings of the Third International Kawasaki Disease Symposium, Tokyo, Japan, December 1988

7. Sagawa K, Katagiri K, Yokoyama MM, Hattori T, Shimazu K, Sato N. Inoue $\mathrm{O}$, Kato $\mathrm{H} 1988$ Attempts to isolate the possible etiological virus of Kawasaki disease. Proceedings of the Third International Kawasaki Disease Symposium, Tokyo, Japan, December 1988

8. Shiraki K Okuno T, Yamanishi K, Takahashi M, Harima Y, Kojima S Ohkuni $\mathrm{H}$, Imaishi $\mathrm{H}$, Onoe $\mathrm{S}$, Nihei A, Nakai M, Ishii T, Ozaki T, Asano $Y 1988$ Trials to isolate an etiologic agent of Kawasaki disease from patient's mononuclear cells. Proceedings of the Third International Kawasaki Disease Symposium, Tokyo, Japan, December 1988

9. Harada S, Tominaga K. Hinuma Y 1988 An attempt to detect a causative agent for Kawasaki disease. Proceedings of the Third International Kawasaki Disease Symposium, Tokyo, Japan, December 1988

10. Burns JC, Huang AS, Newburger JW, Reinhart AL, Walsh MM, Hoch S, Leung DYM 1990 Characterization of the polymerase activity associated with culture peripheral blood mononuclear cells from patients with Kawasaki disease. Pediatr Res 27:109-112

11. Gimbrone MA 1976 Culture of vascular endothelium. Prog Hemost Thromb $3: 1-28$

12. Monroe JE, Andrews C, Sullivan JL, Mulder C 1987 Use of cytoplasmic dotblot hybridization to detect human immunodeficiency virus RNA sequences in cultures of peripheral blood. J Infect Dis 155:320-322

13. Andrews CA Sullivan JL Brettler DB, Brewster FE, Forsberg AD, Scesney S, Levine PH 1987 Isolation of human immunodeficiency virus from hemophiliacs: correlation with clinical symptoms and immunologic abnormalities. J Pediatr 111:672-677

14. Hoffman AD, Banapour B, Levy JA 1985 Characterization of the AIDS associated retrovirus reverse transcriptase and optimal condition for its detection in virions. Virology 147:326-335

15. Rowley AH, Shulman ST 1987 The search for the etiology of Kawasaki disease. Pediatr Infect Dis J 6:506-508

16. Leung DYM, Chu ET, Wood N, Grady S, Meade R, Geha RS 1983 Immunoregulatory $\mathrm{T}$-cell abnormalities in mucocutaneous lymph node syndrome. J Immunol 130:2002-2004

17. Burns JC, Huang AS, Newburger JW, Rosen FS, Leung DYM 1988 Characterization of polymerase activity associated with cultured peripheral blood mononuclear cells from patients with Kawasaki disease. Proceedings of the Third International Kawasaki Disease Symposium, Tokyo, Japan, December 1988

18. Mack DH, Sninsky JJ 1988 A sensitive method for the identification of uncharacterized viruses related to known virus groups: hepadnavirus model system. Proc Natl Acad Sci USA 85:6977-6981 